Bryant University

Bryant Digital Repository

\title{
Representing Heritage and Loss on the Brittany Coast: Sites, Things and Absence
}

Maura Coughlin

Bryant University

Follow this and additional works at: https://digitalcommons.bryant.edu/eng_jou

\section{Recommended Citation}

Coughlin, Maura, "Representing Heritage and Loss on the Brittany Coast: Sites, Things and Absence" (2012). English and Cultural Studies Journal Articles. Paper 39.

https://digitalcommons.bryant.edu/eng_jou/39

This Article is brought to you for free and open access by the English and Cultural Studies Faculty Publications and Research at Bryant Digital Repository. It has been accepted for inclusion in English and Cultural Studies Journal Articles by an authorized administrator of Bryant Digital Repository. For more information, please contact dcommons@bryant.edu. 


\title{
Representing Heritage and Loss on the Brittany Coast: Sites, Things and Absence
}

\author{
Maura Coughlin \\ Department of Literary and Cultural Studies, Bryant University, Smithfield, RI, USA \\ Correspondence: mcoughli@bryant.edu
}

This is an essay about the interplay of objects, art and visual culture in several community museums and historical sites dedicated to local social history in coastal Brittany. There, in the later nineteenth and early twentieth centuries, Breton maritime culture invented a range of compensatory ritual objects, sites and practices to account for loss of life at sea. The presentation of this material culture of mourning in small museums, regional museums and ecomuseums on the Breton North Coast and the islands of Sein and Ouessant are examined in this essay. These material objects once bore material witness to crucial moments in the life of the family and today serve to represent the community's collective memories and to narrate the community's heritage to the outside world. In several cases examined in this essay, literary representations, art and visual culture are compared to heritage sites and museums. Methodologies are drawn from social art history, studies of tourism and collecting, museum studies, material culture studies, and feminist interests in the politics of the everyday.

Keywords: Brittany; material culture; ecomuseum; death; Ouessant; Sein; mourning

According to historian Françoise Péron (2000), the notion of a formalised French maritime heritage is a recent invention of the late twentieth century. Up until the 1960s, she contends, the modern French nationalist myth conceived of the nature of France as primarily rural and agricultural: a cultivated land without wilderness. However, over the course of the past three centuries, the coast has been imagined, inhabited, used and described in ever-changing ways. The sea and shore, prior to the eighteenth century, best exemplified a notion of an unruly, primeval place. In the later eighteenth century, a theologically informed view of the seacoast as wild, dangerous and monstrous fades, and is replaced by the Grand Tour aesthetic of sublime beauty. As the later nineteenth-century notion of the seaside holiday encouraged a newfound appreciation of the beach and of sea bathing, the nation's edges became increasingly desired spaces, constantly reinvented through visual and literary representation. Yet the emerging modern attitudes referenced in this brief overview (surveyed in Alain Corbin's social history La Territoire du Vide 
(trans. Lure of the Sea, 1994) are primarily those of visitors to the coast, rather than its residents. Cultural geographer Allan Pred (1984, p. 279) encourages us to think of the idea of place "as a process whereby the reproduction of social and cultural forms, the formation of biographies, and the transformation of nature ceaselessly become one another" and where place is not only what is observed but also what continuously takes place. Thus a landscape is something always in process and always historically contingent. This essay considers ways in which recently institutionalised collections displaying the maritime heritage of coastal Brittany frame this past and construct meanings of place in an active and ongoing process of representation for both residents of and visitors to the region. In addition to formal museum collections, related sites of memory and other forms of visual culture in Brittany are discussed in terms of the ways in which they invite the viewer to re-imagine the maritime past of this place and suggest present orientations as well. Research into the local, cultural meanings of place and commemoration has been motivated by my interest, as an art historian, in artists working on the Brittany coast in the late nineteenth century, and, in particular, the work of Charles Cottet and his exploration of dark themes of death and mourning in Brittany. This essay responds to the work of art historian Nina Lübbren, who notes that "a small but growing number of art historians has begun to reconstruct the complex ways that geographic locations intersected with the production of cultural representations, particularly in late nineteenth-century France"(115). My interest is in the ways in which visual images, collected objects and historical sites in coastal Brittany collectively contribute to sense of place of the region; thus my examples are examined in dialogue (in the construction and representation of place) rather than as relatively "authentic" indexes of historical experience.

\section{Travel Narratives of Backward Brittany}

From the medieval period to the French Revolution, the Breton peninsula had shifting allegiances to the rest of France. With sea on three sides and marshland to the east, it was geographically isolated from the continent. Bretons had great mobility along the coast and over the sea however, and their culture has shared many aspects of language, folklore and popular religious practices with Celtic countries of the Atlantic seaboard that were networked by water travel (Cunliffe 567). In ethnographic collections of folklore gathered in the late-nineteenth and early twentieth centuries such as Paul Sébillot's Contes des paysans et des pêcheurs (Tales of peasants and fishermen) (1881) and Le folk-lore des pêcheurs, (Fisher Folklore) (1901) the oral cultures and everyday experiences of coastal Bretons are depicted as analogous to other Celtic 
fishing communities. The common Celtic culture of fisher folk of the Atlantic repeats in the collections of folklorists well through the mid-twentieth century (Anson 1965).

French writers visiting coastal Brittany in the eighteenth century often depict it as a wasted, impoverished or exotic place (Salomé 2003). As an interest in Celtic culture grew with the foundation of the Académie Celtique in Paris in 1804, the ethnographic project began of collecting the 'vanishing' superstitions and folklore of Celtic Brittany (Gerson 1996, Ozouf 1981). One of the earliest travel writers to explore Brittany was the Académie's founder, Jacques Cambry (1799) who was charged with drawing up an inventory of monuments that had survived Revolutionary iconoclasm, (Corbin 1994). Cambry's itinerary is the kind of story that "transforms places into spaces or spaces into places" (Decerteau 1988, p. 118). His representation of sublime Brittany is reiterated by many artists, writers and photographers throughout the nineteenth century who imbue their images of the Brittany coast with mythic resonances, viewing the people as primitive guardians of legends and reservoirs of lost Celtic and Druidic culture.

Many artists employed a type of "documentary romanticism" in depictions of everyday coastal life in the seasonal artists' communities at Pont-Aven, Concarneau, Douarnenez, PerrosGuirec, etc., giving their intended viewers a sense of authentic "privileged access" to ancient ways of life surviving in the modern world (Lübbren, 40). Similarly, travel writers repeatedly describe attitudes and practices of the locals that exemplify Brittany's fossilised backwardness and obstinate resistance to modernity (Corbin 1994). Over the course of the nineteenth century, narratives of travels in Brittany gradually come to value, then later celebrate the region as a repository of ancient culture and vestigial ritual lost to metropolitan France (Bertho-Lavenir 1908). At the most extreme edges of Brittany seemed to be the most 'pure' or concentrated repositories of human culture, languages and even animal species that had died out elsewhere: these were the Breton islands of Sein, Ouessant, Molène, Groix, Batz, and Belle-Isle: places that had been described since the late eighteenth century as remote, wild, mysterious sites of ritual. As this formerly marginal edge of the French nation became central to an understanding of national heritage, and in turn became a desired space, its past was reinvented in the process of being preserved. ${ }^{\mathrm{i}}$

Folklore scholar Pertti Anttonen shows that the concept of modernity has often been constructed through representations of cultural difference (2005, p.27), and that "in folkloristic discourse, tradition has not meant indigenous practices to be continued, preserved or revitalised, but instead, the concept has stood for representations of national antiquity that were to be valorised and nostalgized but also to be left behind in order to have them speak for a national 
capacity for historical progress toward statehood and modernity" (2005, p.177). Thus, in Anttonen's words, these travel accounts of "vanishing folk traditions have served the production of modernity" (2005, p.26). Can regional tradition also serve the production of identity of a modern place without always constructing value-laden, binary differences between the past and present?

\section{Sites of Death, Mourning and Memory in Brittany}

A folkloric association of the sea with death and loss is established in nineteenth-century visual and literary culture and is maintained as a historical attitude that speaks of place and memory in many preserved sites along the Brittany coast. The retention of Celtic death practices and superstitions in coastal Brittany was given its fullest elaboration in the collections of folklore, travelogues and fiction published by Breton scholar Anatole Le Braz. His popular text Legende de la Mort chez les Bretons Armoricains (Death Legends in Coastal Brittany, 1893) details Bretons' persistent faith in death omens and superstitious demons. The dangerous and doomed lives of Breton fishermen from the North Coast area (Côtes d'Armor) surrounding Paimpol who fished the long cod season on the banks of Iceland or Newfoundland for the better part of a year were romanticised in the novels Mon Frère Yves, (My Brother Yves, 1883) and Pêcheur d'Islande (Iceland Fisherman) (1886) by Pierre Loti. Although they are clearly marked by romantic and symbolist tastes of their day, the texts of both Le Braz and Loti are repeatedly invoked as contextual, historical explanations of historical sites, material culture and collections of regionally specific art in museums and historical sites in Brittany. As has been extensively studied, Loti's romance of the life of the sea had a wide appeal for visual artists in the 1880s and 90s (Soth).

\section{Material Memorials and Lost Bodies}

The village of Ploubazlanec on the North Coast was made famous as the setting for Loti's Iceland Fisherman. In this sad tale of frustrated love and loss, the young fisherman Yann, like so many of his family, is fated a watery death as his new bride, Gaud, almost hopelessly awaits his return, looking to sea from a high point in the town where stands a stone monument known as the "Widow's Cross." Because so many from this village died at sea and their bodies never returned to the home soil, mourners lacked both the emotional closure of proven death as well as the physical body as a ritual focus. Consequently, the cemetery in Ploubazlanec has a famous Wall of the Disappeared at Sea to which were affixed homemade cenotaphs and plaques, standing in for those the ground is missing (Figure 1). 


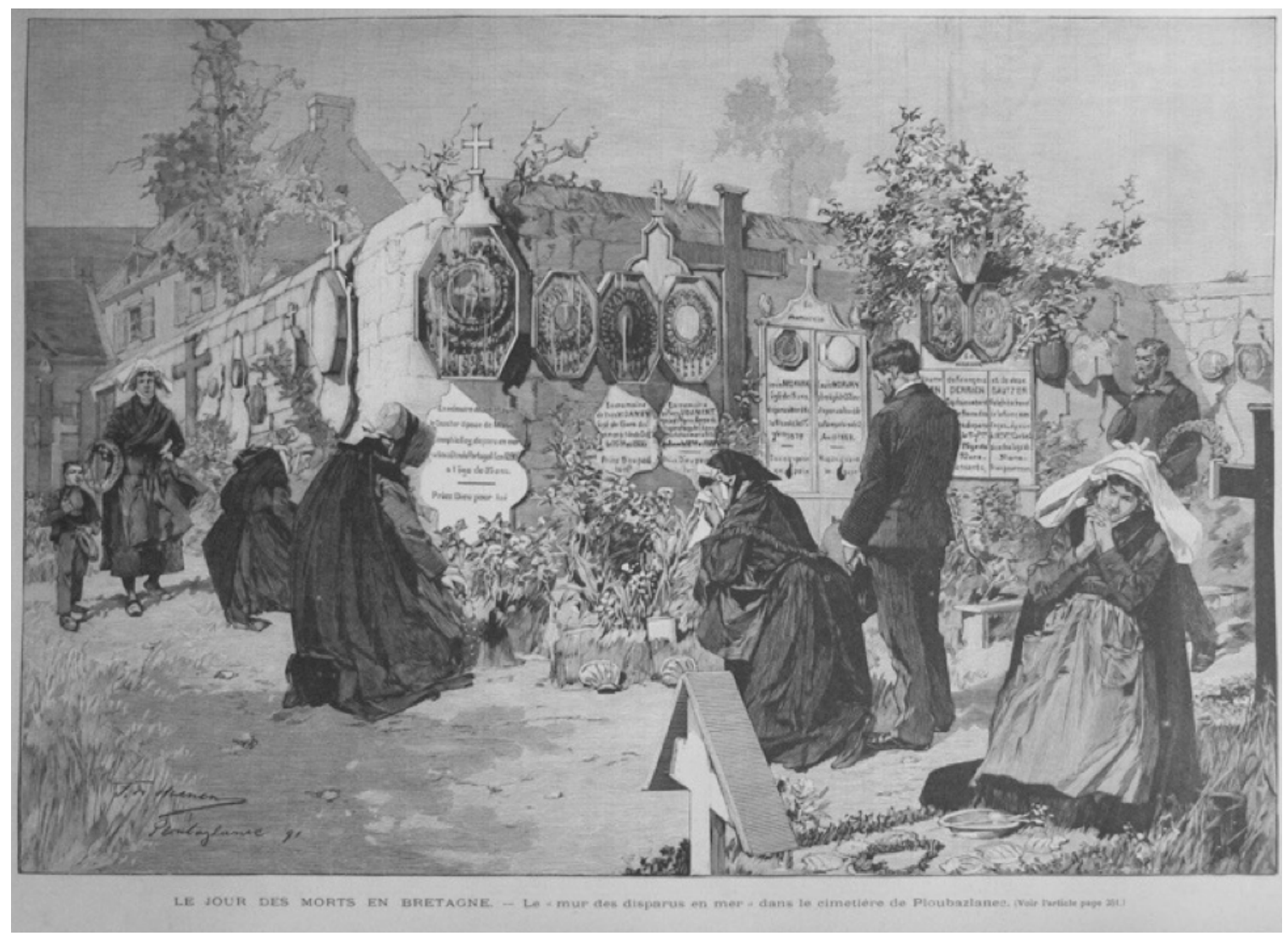

Figure 1. Wall of the Disappeared at Sea, Ploubazlanec in L'Illustration, (n. 2540) 31 October 1891. Author's collection.

Images of pious Breton widows attending to graves, throwing wreaths into the sea or grieving at this wall on Toussaint (All Saints' Day, November $1^{\text {st) }}$, appear with frequency in fin de siècle French paintings and prints as well as the illustrated Parisian papers L'Illustration (1897) and Le Petit Journal (1911, 1924) (Figure 2). The festooned wall in Ploubazlanec also appears repeatedly in other forms of popular imagery such as postcards and in travel literature of the early twentieth century. 


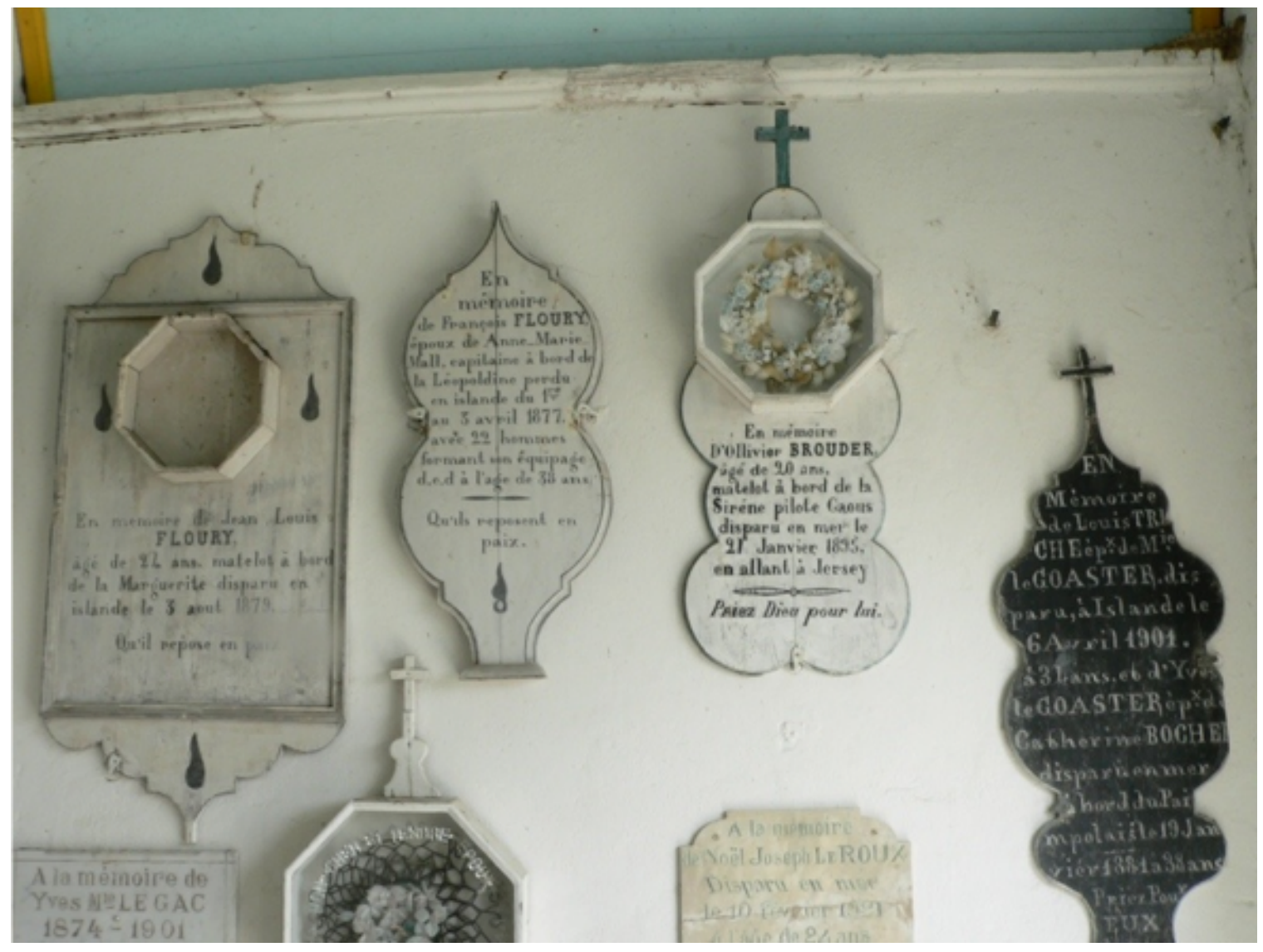

Figure 2. Original wooden cenotaphs originally found on the Wall of the Disappeared at Sea. Photographed by the author in the porch of the church of Perros-Hamon, Ploubazlanec, May 2008.

In 1939, the graveyard wall was rebuilt and the homemade memorials to the lost at sea were moved into the nearby eighteenth-century chapel of Perros-Hamon where they can be found under the sheltered porch: a space somewhat like an open air-chapel. The touching and fragile nineteenth-century wooden cenotaphs follow no particular, prescribed form, but many offer a prayer and detail the place and approximate date of death as well as the age of the deceased. As Loti's character Gaud remarks, the family names repeat for several generations, and spaces have been left for those the sea will claim (Viaud (pseud. Loti) 1888, p.82). The original plaques have been replaced them on the stone wall by durable marble slabs and simple, painted wooden plaques.

Today, as one approaches the wall from the cemetery's entrance, a polished granite slab affixed to the wall tells of the lost at sea. Imbedded in its surface are two reproduced postcards: one, from the early twentieth century, depicts a women cloaked in widow's weeds and another kneeling before a plaque on the wall prior to its rebuilding, the other image depicts "La Glycine," the last cod boat to depart for Iceland in the 1930s- A visit to the site is framed by these 
representations that are further echoed in the small, nearby community museum, Mémoire d'Islande (Remembering Iceland), that was founded in 1994 in the former house of a fisherman, François Le Buhan, who had made three long trips to Iceland. The collection displays such objects as costume, letters, model boats, navigation gear and photographs given from family collections of the immediate community. On its website, the commune of Ploubazlanec (2010) presents itself as if an open air museum, inviting the visitor to view the collection in Mémoire d'Islande as the focal point of a route that includes the Wall of the Disappeared, the PerrosHamon chapel, the nineteenth-century chapel of the Trinity (with an imposing altar to Our Lady of the Shipwrecked) and the Widow's Cross that marks a dramatic vantage point for looking to sea. Almost all of these sites are mentioned in Loti's novel and many of the village streets have been renamed to even more tightly bind the place to its literary representation. As Lübbren explains (in the context of the artists' colony) “[b]y a process involving over-simplification, stereotyping, labelling and activating prejudices, these conceptions crystallise into symbolic formations... [c]ollectively, a group of place-images makes up a place myth: a set of widely held and distributed core-images toward which individuals orientate their experiences. Place-myths are powerful motors of meaning, and they stubbornly continue to govern what people think of a place even when it no longer conforms to the images" (116). The summer homes and manicured lawns of this seaside town speak to new uses of this landscape as valued vacation real estate in a region that re-enacts the Iceland fishermen's pardon as pure tourist spectacle.

\section{Maritime Memory and the Ecomuseum}

Although Mémoire d'Islande in Ploubazlanec does not have the official designation of ecomuseum, the way in which it functions as part of a broader constellation of sites relates to this museological concept that originated in the post-1968 cultural turn of "new museology." The Ecomuseum was developed in France with the goal of opening up natural, living cultural heritage to a broader spectrum of society (Davis 1999, p. 54). In 1971, Hugues de Varine coined the term “ecomuseum," (écomusée) referencing an environmental concept of "écologie." As a democratizing approach to cultural heritage, the ecomuseum was proposed as an inclusive alternative to state run, bureaucratic, centralised, professionally curated, often elitist institutions (Stone and Planel 1999). In one of its most radical formulations, Québécois Museum administrator René Rivard in 1984 characterises these relationships: "traditional museum (= building + collections + experts + public $)$ to the ecomuseum $(=$ territory + heritage + memory + population)" (Rivard cited in Davis 2005, p. 371). In an influential manuscript often cited in later texts on the ecomuseum, Rivard makes a radical call for "repersonalizing" the local with a 
museum of living, collective memory (rather than the 'temporal vector' of the valorised past) that in its more extreme assertions has "no need for specialization, historians, folklorists or nostalgic or callous tourists" (1984, p. 45-46).

As it was theorised, the ecomuseum had a somewhat utopian scope: broad enough to encompass a natural and cultural landscape, local heritage, dialects, and sense of place along with the objects, archives and images that might be contained in a building (Davis 2005). It was to provide "a mirror in which a population could seek to recognise itself and to explore its relationship to the physical environment as well as to previous generations; also an image offered to visitors to promote a sympathetic understanding of the work, customs and peculiarities of a population" (Poulot 1994, p.66). An ecomuseum's success was to depend upon community agreement, support and involvement; it promised to give back to the community by retaining local character, fostering sustainable businesses, promoting festivals and thereby aiding the economic regeneration of rural areas, in part through cultural tourism.

What differentiates the ecomuseum from sites of staged heritage tourism (like the Iceland Fishermen's pardon) is that the ecomuseum's focus must be determined by its local population rather than being imposed from the outside (Davis 1999, p. 69). Because "the complexity of place and what it represents to individuals and communities" are elusive qualities that cannot be contained by a traditional museum that can only collect and display "fragments," an understanding of place must come from a dialogue between collections of material culture and the environment that surrounds it (Davis 2005, p. 368). The ecomuseum is thus a way of interpreting, producing, performing and maintaining a sense of place or locality; as geographer Doreen Massey explains, our contemporary understanding of "localities are produced by the intersection of global and local processes - social relations that operate at a range of spatial scales" (Massey cited in McDowell 1991, p. 4). Peter Davis (2005, p. 366), writing on the social meanings of the term "environment" in the context of the ecomuseum, notes that features of place such as worked landscapes, material culture and local ways of life are "cultural touchstones" that evoke the significance of place when valued in protected sites and museums.

The first official ecomuseums were connected to the establishment of the Parc Naturel Régional d'Armorique in Finistère (Western Brittany), and one of these was the Ecomusée de l'Ile de Ouessant that eventually included two houses, a lighthouse and a windmill. Many ecomuseums, likewise, encourage the visitor to make contact with various "antennae" sites in the landscape that inform an intangible sense of place that the museum aims to conserve and promote (Davis 2005, p. 368). La Maison du Niou Uhella (which later became the centerpiece of the Ecomusée de l'Ile d'Ouessant), has been called the "premier ecomuseum of France" (Davis 2005, 
p. 368). It opened in July of 1968, prior to the invention of the category, in the tiny hamlet of Niou Uhella on Ouessant. It is a slate-roofed, stone cottage, in which compartmentalised spaces of two rooms served as kitchen, dining room and bedroom. Its design is typical of house styles c. 1900 (at about this time of relative prosperity many families replaced thatch roofs with slate) (Péron 1994, p.32). Connected to the house is a small museum displaying in glass cases objects and costumes from the history of the island. The trim, walls and furniture are painted white and bright blue - a colour with Marianic overtones, favoured at about this time. As Péron (1997, p. 200) notes, the interior is arranged like a boat but ornamented like a chapel: small passages of living space weave through the box-beds, armoires and enclosed hearth. Over head are suspended colourful reflective glass balls (Péron 1994). The hearth is surrounded by pious images such as statuettes and popular Epinal and chromolithographic prints (Simon 1997, p. 265).

As suggested by the Niou reconstruction, elaborate domestic altars in coastal homes were the meeting place of private loss and global travel (Simon 1997). Here, on the open dish racks on the walls, marriage globes and devotional statues are sandwiched in between dinner plates and exotic colonial souvenirs brought back from men's travels at sea (Péron 1994, p.208). The minimal "male" intervention in the interior of the home is telling of the general absence of men from everyday life on the island: men and boys shipped out frequently for voyages of six or seven years. The reconstructed décor and layout of the domestic space is a bit more stripped-down, clean and prosperous looking than a widely read travel account written in 1895 would have us believe: the narrator, Victor Eugène Ardouin-Dumazet, describes a typical Ouessantine cottage as having granite mortarless walls, a straw roof, a beaten earth floor, only a few kitchen utensils, a meagre fire made of gorse twigs and dried cow droppings, very little light, and close, humid smells that came from one enclosed bed shared by the entire family $(1895$, p. 287). 


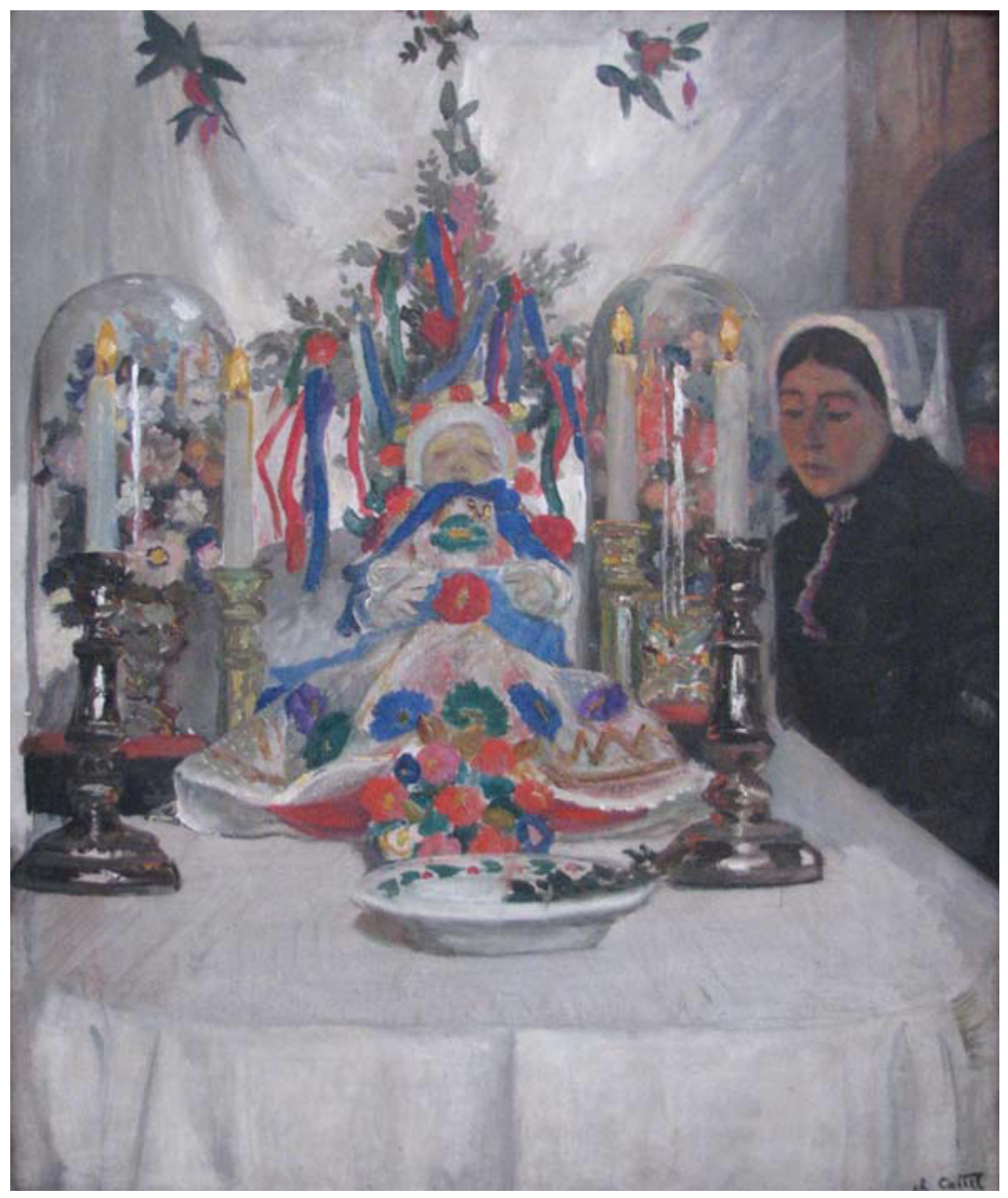

Figure 3. Charles Cottet, Wake of a Dead Child on Ouessant (1897) Quimper Museum of Fine Arts, photographed by author, July 2010.

\section{Presenting the Custom and Costume of Mourning}

The compact interior space of a very similar Ouessantine cottage is the setting of a series of dark paintings by Charles Cottet from 1897 depicting a dead child on Ouessant (figure 3) (several from this series can be seen in the Quimper Museum of Art). On one of his many visits to this island, Cottet witnessed a moving home wake in which a child was laid out on the family's one table, dressed in a christening gown and surrounded by candles, marriage globes and paper flowers. As was the practice in much of Brittany, the walls were covered with white linens to purify the domestic space and to transform the mundane function of the dining table to the 
corpse's ritual space of presentation (Badone 1989: 62). In all versions of the image, Cottet shows us an unsettling convergence of the living and dead, as women gather by the side of the child who is presented as if an uncannily beautiful still life (Coughlin, 2009). The abrupt contrast between this traditional, material approach to death and a modern alienation from death's physicality was as evident when the painting was first shown in Paris as it is now when viewed in the Quimper museum (Coughlin 2009).

The specific material practices of the islanders in the home wake that Cottet represents are echoed in the small displays of objects and images representing everyday life in the ecomuseum on Ouessant. The collection highlights gradual changes in costume from the early nineteenth to mid twentieth century. As in other local collections of material culture such as the Musée Bigouden in Pont l'Abbé, the Musée du Patrimoine in Pont-Croix, or the Musée d'art et d'histoire des Côtes-d'Armor in Saint-Brieuc (North Coast Museum of Art and History) the Maison Niou Uhella on Ouessant displays costume, such as widows' capes and bonnets from the region in order to represent the nineteenth and early twentieth-century culture of death and mourning in coastal communities. In the mid nineteenth-century, Ouessantines adopted the mourning customs of mainland Finistère in which a heavy black woollen cloak, fastened with a silver clasp at the neck, was worn to the wake, the funeral and high mass for several Sundays following the death of a close relative (Coughlin 2009). These same cloaks are so often represented in popular imagery and paintings (by Cottet, Richon-Brunet and others) that describe women's culture of mourning and memory on the Brittany coast.

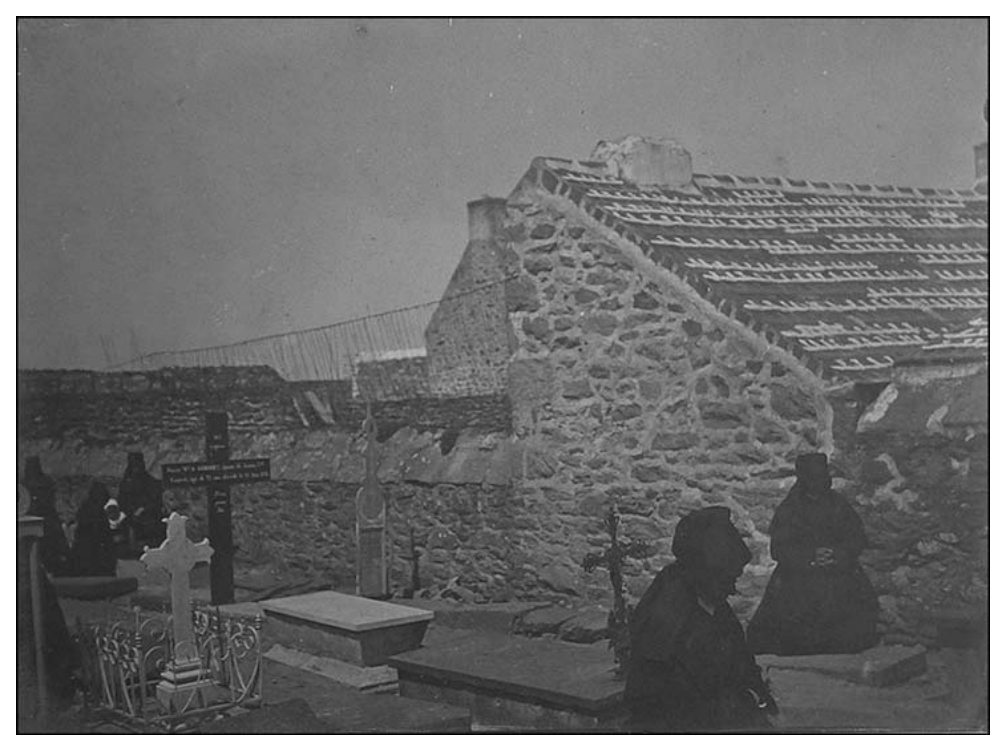

Figure 4. Widows on graves in the churchyard of the Isle of Sein from the album of images shot by "Lemoine" for Anatole Le Braz, 1893. (By permission of the CRBC-UBO Brest). 
Similarly on the island of Sein, women's mourning costume is often described in visual and literary representations of everyday life on the island. After several devastating cholera epidemics from the mid-nineteenth century onward, the women of Sein adapted their daily costume to reflect their almost constant state of mourning the departed. Their black coiffe or "jibilinenn" had two side flaps that when folded down indicated one was in mourning. Elderly women often left them this way for good (Tanguy 1999, p. 22) and after the epidemic of 1886, most women wore this mourning coiffe as everyday costume. When LeBraz visited Sein in 1893, accompanied by a photographer, he returned with several striking images of the island's widows (Figure 4). He most likely had a very prominent Salon painting on his mind: Emile Renouf's massive canvas, The Widow of the Isle de Sein (1880) that had established the theme of Sein as an island of tragic widows. The women of coastal Brittany led everyday lives extremely tied to a local sense of place: rarely leaving their home villages except for religious festivals or necessary expeditions to a nearby market. In the costume displays of regional museums of everyday life such the Musée du Patrimoine in Pont Croix, the local and material specificity of mourning costume has come to stand for this past way of life.

\section{Maritime Memory and Popular Imagery}

Popular imagery that decorated the walls of cottages such as Uhella Niou also speaks of past relationships of place and environment that depended upon gender difference and the mobility or fixity that everyday life of Breton coastal culture assigned to gender. For example, the popular print, Nôtre Dame de Grace was produced by a major publishing house in Normandy and was widely reproduced and sold at maritime pardons (discussed below) (Musée De La Marine 1981) (Figure 5). 


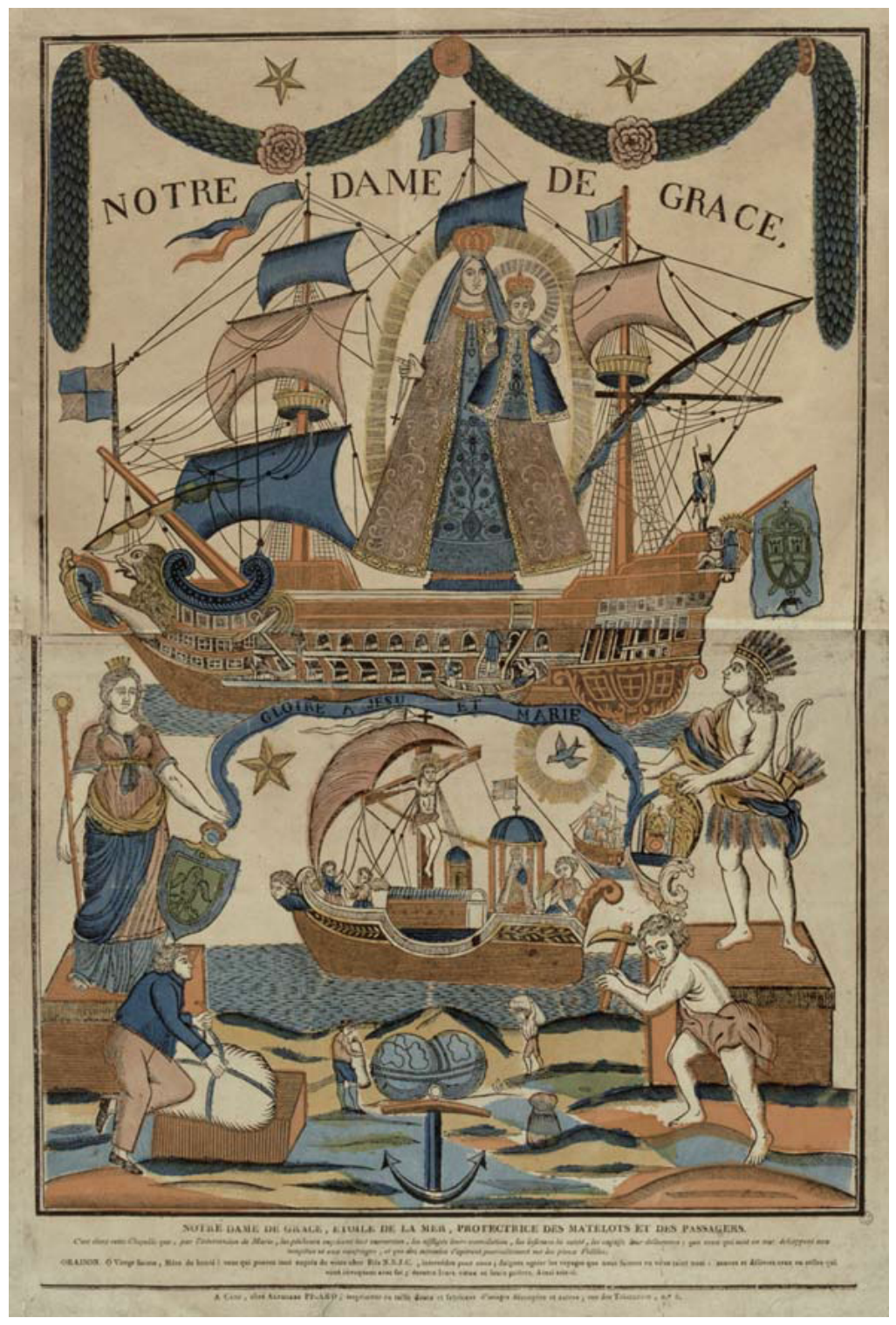

Figure 5. Popular print titled Notre-Dame de Grâce, étoile de la mer, protectrice des matelots, et des passagers (Our Lady of Grace, Star of the Sea, Protector of Sailors and Travellers). 1831-1835. Printed by Alphonse Picard, Caen (Normandy) 81.4 x $54.1 \mathrm{~cm}$. Photo: Jean-Gilles Berizzi. Photo Credit : Réunion des Musées Nationaux / Art Resource, NY, Musée des Civilisations de l'Europe et de la Méditerranée, Paris, France.

Mary here is presented as patron saint of both sailors and travellers: she stands upon a flying galleon: the famous ship of Don Juan of Austria, Christian vanquisher of the Turkish fleet in 1571. Included are allegories of Europe and a "savage" America and a second boat, with a crucified Christ on its mast, making another spiritual voyage. The journey at sea is conflated with the journey of life; the travels of a sailor encompass the local and global, the historical and colonial. A fusion of tradition and modernity, sequential narrative and allegory, these souvenir prints, when viewed in the space of the home potentially generated a range of narratives for their everyday viewers. And these travel narratives were undoubtedly shaped by gender; for families in 
coastal villages were seasonally divided: able-bodied men and boys shipped out for months -- if not years -- at a time. Women's lives were as intensely rooted to the local, as the men's were nomadic, fluid and global. The popular imagery of many other mass-produced prints filled the imaginations of children and women who stayed behind with tales of the high seas and distant lands (Mollat, 2006, p. 31).

\section{The Material Culture of Maritime Memory}

Breton men's experience of place and environment is often represented in local collections and other historical sites through the image of the ship. In a large-scale painting of 1898 in the Quimper Fine Arts museum, The Ex-Voto (Figure 6), Henri-Paul Royer depicts a shipwreck survivor who has made a barefoot pilgrimage (accompanied by his wife and children) to give a votive ship in offering of thanks to the statue of the Virgin and child in the Chapel of SaintTugen, near the port town of Audierne. Chapels all along the coast have such votive boats suspended from their rafters, as in the Chapel of Notre-Dame de Rocamadour in Camaret, whose wooden roof resembles the interior of a ship's hull. ${ }^{\text {ii }}$ Many coastal Breton towns have chapels devoted to Mary, Virgin of the sea, and Saint Anne, who were both thought to be protectors of fishermen. Sailors typically made pilgrimages to these sites for religious pardons before long voyages, or marched in penance and thanks after a safe return because of "a vow made during a storm at sea, or other occasions of danger, to make a pilgrimage to one of her shrines if they are saved. Very often the voeu included going barefoot and bare-headed, dressed only in shirt and trousers, and fasting on bread and water" (Anson 1965, p. 69). Pilgrimages such as this could be taken on singly, but maritime pardons were large-scale events that increasingly came to be seen as spectacles of heritage, rather than expressions of piety and thanksgiving for safe returns. Votive boats were paraded through the streets of a port town during sailors' and fishermen's pardons and blessings of the fleet and are often represented in paintings and popular imagery of Breton festive religious culture. In Paimpol, a winter pardon dedicated to cod fishermen departing for the Iceland sea began in 1855 but, due in part to the popularity of Pierre Loti's melodramatic novel, it became a secular summer heritage festival in 1904. As the cod fisheries died out, so did many pardons for those departing for the Icelandic and Newfoundland banks - however, the Newfoundland fisherman's pardon was reborn in a new location as a spectacular summer heritage festival in St. Malo in 1926 (Lacombe 2001; Young 2007). 


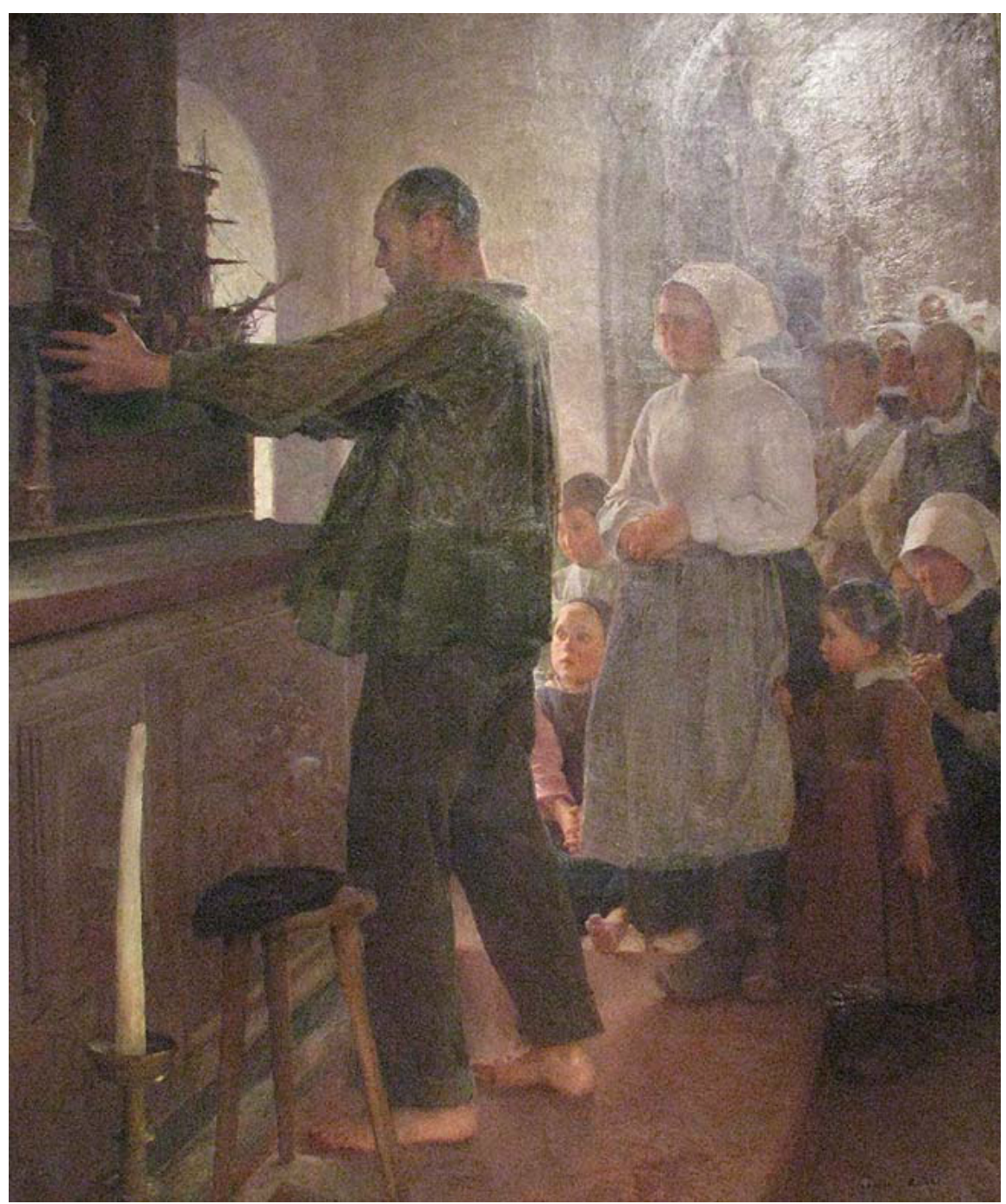

Figure 6. Henri Royer, The Ex-Voto, 1898 Quimper Fine Arts museum, photographed by the author, July 2010.

\section{In Modernity at Sea: Melville, Marx, Conrad in Crisis, literary critic Cesare Casarino} examines modern narratives of the ocean voyage using Michel Foucault's notion of the boat as a heterotopic space:

the boat is a floating piece of space, a place without a place, that exists by itself, that is closed in on itself and at the same time is given over to the infinity of the sea and that, from port to port, from tack to tack, from brothel to brothel, it goes as far as the colonies in search of the most precious treasures they conceal in their gardens (Foucault 1967 cited in Casarino 2002, p.13).

Breton sailors' work for the merchant marine and in the global commerce of marine fisheries meant that they inhabited such indefinable, fluid, heterotopic spaces in sharp contrast to the 
rooted sense of place experienced by their wives, mothers and sisters on the Brittany coast. The votive boat, displayed as an icon of maritime heritage, whether in a regional or local museum or in a chapel, is one aspect of material culture that can speak for the lives of those who travel on the sea and their experiences of uncertainty and loss (rather than romanticised lives of freedom and adventure).

An official tourism website for the Cotes d'Armor (2010) promotes a heritage tour of "chemins marins" or "sailors' paths": a route of devotional sites for fishermen along the Brittany coast. Each section of the guide to this tour (downloadable as pdf) opens with a quotation from Loti's Iceland Fishermen (further bolstering its status in crystallizing the "place myth") and offers lists of chapels, crosses, sculptures, cemeteries, benedictions, ex-votos made at sea in bottles, painted on panels, in stained glass windows, etc. that trace material signs of the maritime past along the Brittany coast. To give just a few more examples of the ways in which tourists are encouraged to view Breton port towns as open-air museums of maritime heritage, Concarneau in Finistère has a medieval, walled ville close in the centre of its harbour that had been devoted to shipbuilding but now contains a floating museum of fishing and services that cater to tourists. Each August, one of the oldest folklore festivals in Brittany, the Fête des Filets Bleus (Festival of the Blue Nets) in Concarneau attracts thousands of costumed participants and many more tourists. The festival was created in 1905 to respond to the Sardine Famine of 1902-5: when the sardines (a single species upon which depended a large canning industry) changed migration patterns for several seasons, they were said to have abandoned Brittany. The result was wide-scale misery and impoverishment along the coast. Since 1993, the port town of Douarnenez (also in Finistère) has declared itself an open-air museum of maritime heritage. Its Port Musée on the waterfront features representative fishing boats from a range of Northern European cultures, and at its centre is the Musée du Bateau that houses smaller fishing boats and provides extensive information on their construction and use. Over two decades of maritime festivals in Douarnenez have drawn thousands of traditional sailing vessels to the port (Mollat 2006, p. 44).

\section{Conclusion}

Outsider modes of representing maritime culture in Brittany, such as Salon paintings, picture postcards and nineteenth-century travel accounts, provided formats for their makers and authors to expound upon their first-hand experiences and to represent their own modernity and worldliness in opposition to that of the locals (Gerson 1996). In these accounts or "place myths," local traditions are often posited as either rigid and unchanging or as in decline after the shock of modernity has infiltrated a former state of stasis. However the conservation of traditional 
practices as well as material, visual and oral culture in the ecomuseum and at other heritage sites, can afford to the local residents ways of both expressing their own everyday experiences of place and remembering the past. These cultural reservoirs may enable residents of and visitors to coastal Brittany to understand and imagine their relationships to place and environment and, in turn, to formulate new responses to contemporary challenges. As coastlines are increasingly being lost to new environmental pressures, these sites and the ecological histories they offer seem ever more fragile points of contact with a former sense of place. As we re-animate sites and collections along the Brittany coast with our presences, responses and subjective associations, its sense of place remains in process.

Maura Coughlin is an art historian of nineteenth-century France, whose recent research is informed by material culture studies, cultural geography, and site specific contemporary art. Social concerns of ecology, memory, mourning and touristic desire intersect with representations and experiences of landscape in the visual culture of death and memory in Brittany. This article is drawn from a larger project, The Visual Culture of Loss and Recuperation in Brittany, 1880-1914.

Many thanks for research assistance in Brittany to Marie-Rose Prigent at the Centre de Recherche Bretonne et Celtique in Brest, Laurence Imbernon at the Musée des Beaux Arts in Rennes, André Cariou at the Musée des Beaux Arts, Quimper and Caroline BoyleTurner in Pont Aven.

${ }^{\mathrm{i}}$ Islands like Ouessant had long been thought of as strategic gateway to France and its coastal waters: invasions, occupations and Irish missionaries had all entered this way (Mollat, 2006, p. 37).

${ }^{\text {ii }}$ François Chappé notes that "the ex-voto is perhaps the most characteristic example of the impossibility of separating spiritual life from its related material objects. The most immaterial aspect of maritime culture, thriving on legends, traditions, superstitions and sayings, was created on boats and quaysides. It was then committed to book, posters and charts, before being transmitted orally in specialized places such as sailors' bars. No approach to religious culture for example is possible unless one traces its transmission via statues, altars, churches, chapels, processional routes or stained-glass windows. Without denying the existence of differing approaches to maritime heritage, it is important to underline the fundamental human unity of the 
heritage process. If this process places the emphasis entirely on artefacts, the latter can be 'understood' only if one knows of the human cultural context in which they were made; if the process centers on cultural practices, the latter are in turn only comprehensible in relation to those artifacts which are an essential part of them and in relation to places in which they occurred" (Chappé 2000, p.110).

\section{References}

Anson, P., 1965. Fisher folk-lore; old customs, taboos and superstitions among fisher folk, especially in Brittany and Normandy and on the east coast of Scotland. London: Faith Press. Anttonen, P., 2005. Tradition through modernity: Postmodernism and the nation-state in folklore scholarship. Studia Fennica Folkloristica, 15. Helsinki: Finnish Literature Society.

Ardouin-Dumazet, V., 1895. Voyage en France. Paris: Berger-Levrault.

Badone, E., 1989. The Appointed Hour: Death, Worldview, and Social Change in Brittany.

Berkeley: University of California Press.

Bertho-Lavenir, C., 1980. L'Invention de la Bretagne: Genèse sociale d'un stéréotype, Actes de la Recherche en Sciences Sociales, 35, 45-62.

Cambry, J., 1799. Voyage dans le Finistère ou État de ce Département en 1794 et 1795. Paris:

Cercle-social.

Casarino, C., 2002. Modernity at sea: Melville, Marx, Conrad in crisis. Minneapolis: University of Minnesota Press.

Chappé, F., 2000. Heritage and history: rocking the boat. In Sarah Blowen, Marion Demossier, Jeanine Picard, eds. Recollections of France: memories, identities and heritage in contemporary France. New York: Berghahn.

Corbin, A., 1994. Le territoire du vide, tr. The lure of the sea: the discovery of the seaside in the western world, 1750-1840. tr. Jocelyn Phelps Berkeley : University of California Press.

Côtes d'Armor, 2010. Chemins Marins, Salle de Presse [online]. Available at:

(http://www.cotesdarmor.com/fr/espace-pro-salledepresse.php accessed 12 Jan 2010.

Coughlin, M., 2009. Crosses, cloaks and globes: women's material culture of mourning on the Brittany coast In Maureen Daly Goggin and Beth Fowkes Tobin, eds. Women and things: gendered material practices, 1750-1950. Hants and Burlington VT: Ashgate, 281-297. Cunliffe, B., 2001. Facing the Ocean: The Atlantic and Its Peoples 8000 BC-AD 1500. Oxford; New York : Oxford University Press.

Davis, P., 1999. Ecomuseums: a sense of place. Leicester: Leicester University Press. ., 2005. Places, 'cultural touchstones' and the ecomuseum. In Heritage, museums and galleries: an introductory reader. G. Corsane, ed. London: Routledge.

Decerteau, M., 1988. The practice of everyday life, Berkeley: University of California Press. Gerson, S., 1996. Parisian litterateurs, provincial journeys and national unity in France. Past \& present 151 (May) 141-73.

Lacombe, P., 2001. The Breton body in culture and religion. Culture, Sport, Society 4 (3), 27-48. Le Braz, A., 1893, Legende de la mort chez les Bretons Armoricains. Paris: Champion. Lübbren, N., 2001. Rural Artists' Colonies in Europe, 1870-1910. Manchester, UK : Manchester University Press.

McDowell, L., 1999. Gender, identity and place: understanding feminist geographies. Minneapolis: University of Minnesota Press.

Mollat du Jourdin, M., 2006. France, the Coast and the Sea. In Pierre Nora, Ed., Rethinking France. Les lieux de mémoire. Vol. 2. Space. Trans. David P. Jordan. Chicago and London: The University of Chicago Press.

Musée de la Marine, 1981. Ex-votos marins dans le monde, Paris.

Ozouf, M., 1981. L'invention de l'ethnographie française : le questionnaire de l'Académie celtique, Annales 36 (2) 210-231. 
Péron, F., 1994. Ouessant. Rennes: Ouest-France.

1997. Ouessant, l'île sentinelle: vie et traditions d'une Île Bretonne. Douarnenez:

Le Chasse-Marée.

2000. Construction of a Breton maritime heritage: processes and signification. In

Sarah Blowen, Marion Demossier, Jeanine Picard, eds. Recollections of France: memories,

identities and heritage in contemporary France. New York : Berghahn.

Ploubazlanec site officiel de la commune, Le patrimoine [online]. Available from:

http://www.ploubazlanec.fr/index.php?page $=$ decouverte\&sousMenu=patrimoine [Accessed 10

January 2010.

Pred, A., 1984. Place as historically contingent process: structuration and the time-geography of becoming places. Annals of the Association of American Geographers 74 (2) 279 - 297.

Poulot, D., 1994. Identity as self-discovery: the ecomuseum in France. In Daniel J. Sherman, Irit Rogoff eds. Museum culture: histories, discourses, spectacles. Minneapolis: University of Minnesota Press, 66-84.

Rivard, R., 1984. Opening up the museum, or, towards a new museology: Ecomuseums and 'Open' Museums. Quebec: Self-published Manuscript.

Salomé, K., 2003. Les îles bretonnes: une image en construction (1750-1914). Rennes: Presses

Universitaires de France.

Sébillot, P., 1881. Contes des paysans et des pêcheurs. Paris: G. Gharpentier. ., 1901. Le folk-lore des pêcheurs. Paris: J. Maisonneuve.

Simon, J.F., 1997. La cheminée dans la maison bretonne. In Gaël Milin and Patrick Galliou eds. Hauts lieux du sacré en Bretagne. Brest: Centre de Recherche Bretonne et Celtique, 257-270.

Soth, L., 1989. Gauguin, Van Gogh and the Fishermen of Iceland. The Burlington Magazine 131 (1033) 296-297.

Stone, P. and Planel, P.,1999. The constructed past: experimental archaeology, education, and the public. London and New York: Routledge.

Tanguy A.,1999. L'île de Sein en 1900: Les textes inédits d'Anatole Le Braz. Armen, 107, 20-29. Viaud, J. (pseud. Pierre Loti), 1883. Mon frère Yves. Paris: Calmann Lévy. .,1886. An Iceland fisherman: a story of love on land and sea. (Pêcheur d'Islande 1886)

tr. from the French by Clara Cadiot. New York: Wm. E. Gallsberger.

Young, P., 2007. Of pardons, loss and longing: tourism and cultural value in Brittany, 19001930. French Historical Studies 30: 237-67. 